\title{
Strategic plan for Academic excellence through Critical thinking for Curriculum Development
}

\author{
M. Muralidhara Rao ${ }^{1}$, Rati Ranjan Sabat ${ }^{2}$, AVNL Sharma ${ }^{3}$ \\ ${ }^{1}$ Professor, Mech Engg, GIET, Gunupur \\ ${ }^{2}$ Electrical \& Electronics Engg, GIET, Gunupur \\ ${ }^{3}$ M echanical Engg, GIET, Gunupur \\ ${ }^{1}$ principal@giet.edu \\ ${ }^{2}$ rati.ranjan@gmail.com \\ 3avnls277522@gmail.com
}

\begin{abstract}
The curricular changes and the enhancement of learning practices, require continuous and strategic transformation. Universities have achieved the enhancement of student learning, that has been implemented across the university as a result of commitment and professionalism across the institution. The current strategic plan of forming global mind set out of university commitments to develop graduates of academic excellence and globally engaged. The technical graduates require leadership and excellence in research and innovation, through new forms of learning methodologies and curricular enhancement.
\end{abstract}

Strategic development in teaching and important issues of learning lies in the contribution of individuals to academics, who are active and innovative in their own disciplinary areas. The needs of the learners are to be translated into strategic approaches and outcomes. Evaluation of outcome based education in the development of teaching and learning leads to excellence in overall value added skill developments. The most useful attributes of technical graduates is the development of critical thinking ability towards advanced learning technologies for overall economic growth and development. The academic curriculum with structured electives to broaden the student technical horizons is essential. The objective of strategic planning is to make realization of embedding the core content and structured electives into academic curriculum.

Keywords: Strategic plan1, critical thinking2, structured electives3, outcome based education4

\section{Dr. M. Muralidhara Rao}

Principal, GIET, Gunupur, Rayagada, Odisha, India, PIN: 765022

principal@giet.edu
Introduction: Over the years, significant steps are carried out to promote teaching excellence within the University and affiliated colleges. The curricular changes and the enhancements to student learning which are implemented in Universities, achieved as a result of the energy, commitment and of "academic excellence through professionalism of academic staff. Current Strategic Plan critical thinking" must be the University's commitment to develop graduates of academically excellent, intellectually literate and globally competent. Development of these attributes in graduates requires leadership and excellence in teaching and learning perspective to implement new modules of learning innovations and curricular enhancement.

The Universities have a strong and growing community of excellent teachers, exemplified by the expertise and continue to contribute to the development of the student learning process. This attempt focuses on the progression of teaching excellence through a strategic plan for teaching \& academic development. Excellence and innovation in teaching-learning are the fundamentals to the delivery of globally focused knowledge. The initiatives promote and develop qualities of teaching leadership, a capacity for innovation on contemporary issues and the capability to influence academic practices and enhancement of learning activity. Emphasis is to be made on the development of strong academic approaches to teaching, learning, assessment and curricular structures. Research is to be initiated on strategic teaching and learning themes through critical thinking and Individual selection of electives related to the main strategic theme.

Promotion of teaching excellence through critical thinking: Critical Thinking Skills are identified as an important aspect of student engagement in learning, and is a valuable graduate attribute. The skills from both teacher and learner perspectives are viewed, through which critical thinking skills are conceptualized and articulated by faculty in the development of modules with the forecast of the technical updates and new add on innovations. The concept of critical thinking skills are subject-dependent and have a strong disciplinary focus, which leads to disciplinary technological development for society/globe. Evaluation is 
an important step to encourage, involve and respond the students in total for critical thinking.

The objective is to see the significance of critical thinking with display of different tasks by pedagogical approaches in realization of the best pathway through critical thinking in students.

Methodology of critical thinking: It can be carried out using a multi-method qualitative semi-structured interviewing and documentary analysis. This involves a structured questionnaire with academics regarding their perspectives of critical thinking.

The main focus will be:

- Towards defining critical thinking held by academia from different disciplines.

- Towards the weightage placed by different disciplines on critical thinking.

- With the pedagogical approaches that can result in critical thinking.

The questionnaire will be circulated with academicians and students selected randomly from different disciplines. The disciplines are selected to ensure a range of sample size which also includes management and science-based one. Questionnaire is in-depth and structured, as per how they define the critical thinking in particular with relation to their own discipline. The participants are asked to set out their views on their discipline, like definitions, concepts surrounding the critical thinking. Participants are also asked about, whether they felt that critical thinking is important for their academics and how it ranked when compared to the other skills. They are asked how they assess and measure the critical thinking.

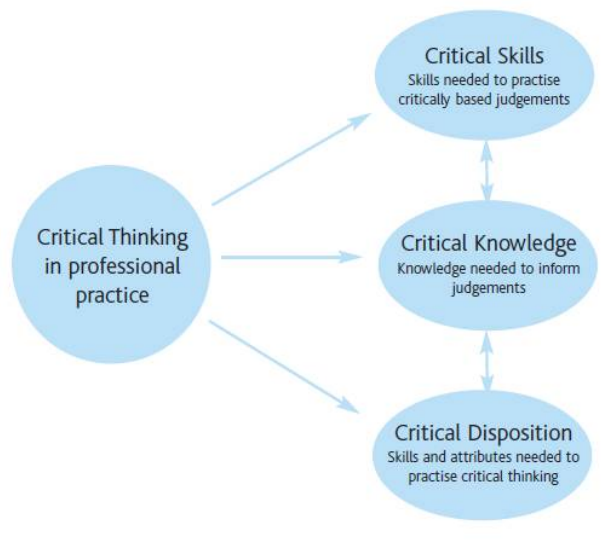

Fig. 1 Analogy of critical thinking

Strategic Development of Structured Electives: Strategic Development of electives is identified as an important curricular aspect of the student learning experience. The scope and outcomes of structural electives encompasses the international benchmarking with a view to identify curricular breadth and depth. Primary goal is to understand the specific aspects of student learning, which are highly transferable across related disciplinary learning outcomes.

The strength lies in the contribution of the individuals to academia, which are active and innovative within their own disciplinary areas. By advancing a scholarly knowledge and development of teaching and learning, proper design through structured electives is achieved for effective outcome based education.

Methodology of Structured Electives: The aim is to contextualize the development of elective provision within a pedagogical educational policy perspective. The effectiveness of offering electives is the flexibility and diversity of experience to students. General academic databases and specialist educational databases are to be employed, as well as within each of the disciplines representing the stake holder's areas of interest. The investigation of structured electives as part of strategic plan at various universities offering electives will describe the actual policies and procedures for setting out their requirement and restrictions.

\section{Models of structured electives:}

- Model 1: Retain the current system (free choice across University).
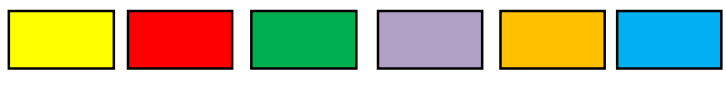

Fig. 2 Free choice model

- Model 2: Modify the current system to encourage students to pursue a greater depth in electives.

The goal of this model is to facilitate both breadth and depth through enabling students to select a combination of electives at levels 1,2 and 3 and from approved modules in one area forming a structured elective.

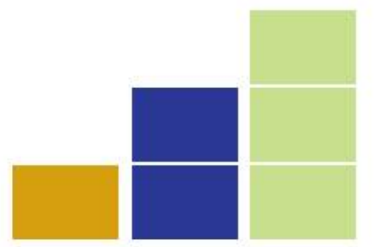

Fig. 3 Combination in elective model

Model 3: Change the current system in light of provision at other universities. Specify sets of modules (areas of study) from which some electives must be taken (e.g. the Yale System).

Changes to the current system would have a number of academic, logistical and resource implications. For example, if the University to suggest, or insist, that students take structured electives involving modules at a level higher than level 1, it would have to ensure that such elective modules were available and that there were sufficient 
places available to satisfy demand.

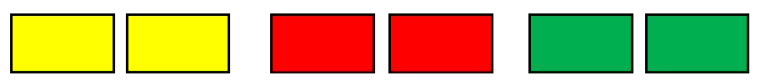

Fig. 4 Structured elective modules

Conclusion: The current curricula available for technical education is of varied proportions which need commonality with strategies of structured electives either choice based or credit based as per the global requirement. As part of critical thinking attainment can be made as a dynamic concept. The educators have to guide the students through cycles of engagement with context bound knowledge, which is abstract and symbolically dense. The process can be initiated by the higher education governing bodies to set up the prospective guidelines and evolve procedures for implementation at various universities and technical educational institutions in India.

\section{References:}

1. A new measure of psychological misconceptions: Relations with academic background, critical thinking, and acceptance of paranormal and pseudoscientific claims DA Bensley, SO Lilienfeld, LA Powell - Learning and Individual Differences, 2014 - Elsevier

2. Davies, M. W. (2008) 'An 'infusion' approach to critical thinking: Moore on the critical thinking debate', Higher Education Research \& Development, 25 (2): 179-193.

3. Abrami, P. C., Bernard, R. M., Borokhovski, E., Wade, A., Surkes, M. A., Tamim, R., \& Zhang, Dai. (2008). Instructional interventions affecting critical thinking skills and dispositions: A stage 1 meta-analysis. Review of Educational Research, 78(4), 1102-1134.

4. Fontana, A. \& Frey, J.H. (2003) 'The Interview: From structured questions to negotiated text'. In Denzin, N.K. \& Lincoln, Y.S. eds. Part I: Methods of Collecting and Analyzing Empirical Materials. London: Sage.

5. Jones, A. (2007a) 'Multiplicities or manna from heaven? Critical thinking and the disciplinary context', Australian Journal of Education, 51 (1): 84-103.

6. Maton, K. (2007) 'Knowledge-knower structures in intellectual and educational fields'. In Christie, F. \& Martin J,. eds. Language, Knowledge and Pedagogy: Functional linguistic and sociological perspectives.

7. Albritton, F. P, (2006) 'Humboldt's Unity of Research and Teaching: Influence on the Philosophy and Development of U.S. Higher Education'.

8. Scott, J. \& Maw, S.J. (2009) 'The role of the postgraduate student in delivering Bioscience
Teaching', Bioscience Education.

9. Dunnion, J., Loughran, H., \& Purcell, P. (2010) 'A tale of two systems: Electives in University College Dublin', Heads of Teaching and Learning Morning. University College Dublin. May 2010.

10. Magennis, S. and McMullin, B. eds. AISHE International Conference: Teaching and Learning in the Changing World of Higher Education. August 2007.

11. Wheeler, Edward and McDonald, Robert, "Writing in Engineering Courses", Journal of Engineering Education, October 2000.

12. Transactional Reading in EFL Learning: A Path to Promote Critical Thinking through Urban Legends Mariela Leal Hernandez, Luis Fernando Gómez Rodríguez Vol 17, No 2 (2015), Leal Hernandez, Colombian Applied Linguistics Journal 